\title{
Smoking among undergraduate students in the area of health
}

\author{
Tabagismo entre acadêmicos da área de saúde
}

Ana Flávia Granville-Garcia ${ }^{1}$

Dmitry José de Santana Sarmento ${ }^{1}$

Jalber Almeida Santos ${ }^{1}$

Tássia Almeida Pinto ${ }^{1}$

Raulison Vieira de Sousa ${ }^{1}$

Alessandro Leite Cavalcanti ${ }^{1}$

${ }^{1}$ Departamento de

odontologia, Universidade

Estadual da Paraíba

(UEPB). Rua Capitão João

Alves de Lira 1325/410,

Bela Vista. 58.428-800

Campina Grande Paraíba. anaflaviagg@hotmail.com.
Abstract The aim of this study was to evaluate the relationship between smoking and socio-demographic and behavioral factors among undergraduate students in the area of health at the State University of Paraíba, Brazil. An analytical crosssectional study was conducted with a representative sample from each of the following courses: Dentistry, Nursing, Psychology, Pharmacy, Physical Therapy and Physical Education. A total of 492 students were interviewed using a structured questionnaire. The chi-square and Fisher's Exact tests were used for statistical analysis at a $5 \%$ level of significance. Smoking prevalence was 5.7\% and stress was the main reason for starting the habit $(36.8 \%)$. In the multivariate analysis by logistic regression, the variables of gender, religious persuasion, semester attended in the course, and alcohol consumption were significantly associated with smoking $(p<0.05)$. Although other studies reported a strong relationship between university students and smoking, the prevalence of smokers was low. Most of the variables studied revealed a correlation with smoking. Since smoking and alcohol consumption are the two major human addictions, this study suggests a bidirectional relationship between these variables.

Key words Smoking, Students, Alcoholism, Epidemiology, Risk factors
Resumo Avaliar a relação entre o tabagismo e os fatores comportamentais e sociodemográficos entre acadêmicos da área de saúde da Universidade Estadual da Paraíba (UEPB). Foi realizado um estudo transversal analítico, no qual foi obtida uma amostra representativa de cada curso (Odontologia, Enfermagem, Psicologia, Farmácia, Fisioterapia e Educação Física). Foram entrevistados 492 alunos por meio de formulário estruturado. Os testes estatísticos utilizados foram Quiquadrado e o Exato de Fisher (significância de 5\%). A prevalência de tabagismo foi de 5,7\% e o estresse foi a principal razão para o início do hábito (36,8\%). Na análise multivariada por regressão logística as variáveis, sexo, prática de religião, período cursado e consumo etílico apresentaram-se associadas ao hábito de fumar $(p<0,05)$. Apesar de estudos relatarem uma forte relação entre estudantes universitários e fumo, a prevalência de tabagismo foi baixa. A maioria das variáveis estudadas demonstrou associação com o hábito de fumar. Sendo o fumo e o álcool as duas maiores dependências humanas, este estudo sugere uma relação bidirecional entre estas variáveis. Palavras-chaves Tabagismo, Estudantes, Alcoolismo, Epidemiologia, Fatores de risco 


\section{Introduction}

Smoking is currently considered a silent pandemic, the most important public health problem and the main preventable cause of death, responsible for the death of 1 in every 10 adults worldwide ( 5 million people per year). If the current patterns persist, smoking will cause 10 million deaths per year by the year 2020. Seventy percent of these deaths will occur in developing countries ${ }^{1}$.

Nicotine addiction has three basic aspects: physical dependence, responsible for the withdrawal syndrome symptoms; psychological dependence, responsible for the feeling of the cigarette as a support in moments of stress, loneliness, threat, etc; and conditioning, due to the usual associations of smoking (smoking and drinking coffee, smoking and working, smoking and driving, smoking after meals, etc $)^{2}$.

Smoking has been identified as the major risk factor for the development of several diseases such as lung cancer, heart, circulatory, coronary and respiratory diseases, nicotine addiction, and sexual impotence in men. Also, it is usually the direct cause of $30 \%$ of cancer cases ${ }^{3-5}$. In addition, smoking is related to psychiatric disorders such as depression and schizophrenia, neurobehavioral developmental disorders such as attention deficit hyperactivity disorder (ADHD), drug abuse, decrease of intellectual performance and alcohol consumption $^{6,7}$.

The World Health Organization (WHO) Framework Convention on Tobacco Control (FCTC) was established in response to the global tobacco epidemic. This is a landmark for public health and was embraced by all WHO member countries on May $21^{\text {st }} 2003$. Brazil signed the FCTC on June $16^{\text {th }} 2003$ and it is effective in the country starting February 2005. The FCTC contains chapters designed to protect the present and future generations from the devastating sanitary, social, environmental and economic results of tobacco consumption and tobacco smoke exposure $^{8}$. Since then, tobacco consumption control has been regarded as an ethical matter and a social responsibility of the governments towards their populations ${ }^{9}$. However, there is a worldwide trend of increased prevalence of smokers among the adolescents and young adults. One third of the world population over 15 years of age smokes and Brazil has approximately 2.8 million smokers in the 5-19-year-old range $e^{1,10,11}$.

College is considered a critical period of vulnerability for the onset of smoking ${ }^{12,13}$. In general, studies reveal a prevalence of smokers varying from $8.5 \%$ to $52.5 \%$ among undergraduate students, with lack of physical activity, alcohol consumption, stress, and engagement in religious practice, among others, being considered as associated factors ${ }^{2,10,14-16}$. Students of health sciences courses deserve special attention in relation to smoking because they will become behavioral models conveying the basic concepts of health into the community. The aim of this study was to investigate the relationship between smoking and behavioral and sociodemographic factors among undergraduate students from health sciences courses of a public Brazilian university.

\section{Methods}

An exploratory cross-sectional study was performed with undergraduate students enrolled in health sciences courses (Dentistry, Nursing, Psychology, Pharmacy, Physical Therapy and Physical Education) at the State University of Paraíba, in the city of Campina Grande, PB, Brazil.

The sample size was calculated based on the prevalence found in an earlier study $(40.7 \%)^{16}$. The population comprised 1,813 students, with random probabilistic sampling proportional to the number of students in each course, using a 95\% $(Z=1.96)$ confidence level and 5\% error margin. The following equation was used: $n=\sigma^{2}$ x p x q x N / E $(\mathrm{N}-1)+\sigma^{2} \times \mathrm{p} \times \mathrm{q}$

Where $\mathrm{n}=$ corresponds to the sample size; $\sigma^{2}$ $=$ confidence level chosen by number of deviations ( sigma); $\mathrm{p}=$ proportion of the characteristics sought in the universe, measured in percentage; $\mathrm{q}=$ proportion in the universe that lacks the studied characteristic $(q=1-p)$, measured in percentage $(\mathrm{q}=100 \mathrm{p}) ; \mathrm{N}=$ population size; and $\mathrm{E}^{2}=$ allowed error estimation. In this way, the minimum sample size comprised 307 undergraduate students. This number was increased by $10 \%$ corresponding to the estimated losses, plus a 1.5 correction factor. After these calculations, the sample size consisted of 507 students.

Data collection was performed by two calibrated researchers between August and November 2008, using a structured questionnaire containing questions related to the smoking habit and associated behavioral and sociodemographic factors: tobacco use, starting age of smoking, number of cigarettes smoked per day, health sciences course and semester attended in the course, gender, age, marital status, engagement in religious practice and physical activity). At baseline, the study purpose was fully explained and the 
participants were asked to sign an informed consent form. The reliability of the responses was tested in $10 \%$ of the subjects by the face validation method, in which the researcher asks the subjects to explain in their own words what they understood about each question ${ }^{17}$. The interviewed subjects showed no difficulty to answer the questions contained in the questionnaire. The cutoff point for definition of smokers was based on a WHO criterion ${ }^{18}$ : "to have smoked 1 or more cigarettes per day for at least 1 month" and of former smokers was: "to have stopped smoking for more than 1 month". The questionnaire was based on previous studies ${ }^{19,20}$.

Data were organized using the SPSS (Statistical Package for the Social Sciences - SPSS Inc., Chicago, IL, USA) statistical software package, presented by descriptive (absolute and percentage distributions) and analytical statistics. Associations among variables were estimated by the cross-products - odds ratio (OR) and 95\% confidence intervals. The chi-square and Fisher's exact tests were used to assess the significance of the associations. Logistic regression models were used for the multivariate analysis with the variable 'response to smoking'. In the initial model were included the variables with $\mathrm{p}<0.15$, and after adjustment only the variables significant at 5\%.

In compliance with the Resolution 196/96 of the Brazilian National Health Council/Ministry of Health on research involving human subjects, the research protocol was recorded at the $\mathrm{Na}$ tional System of Information on Ethics in Research Involving Human Beings (SISNEP) as well as submitted to and approved by the Research Ethics Committee of the State University of Paraíba, Brazil.

\section{Results}

Thirteen students refused to take part on the research, reducing the sample size to 492 undergraduate students aged 17 to 50 years (mean age $=22.20 \pm 4.34$ years; median of 21.00 years). As to gender distribution, $39.2 \%$ were males and $60.8 \%$ females.

Table 1 shows that most of the subjects were enrolled in the Nursing course $(22.4 \%)$, half of them were attending up to the 4 th semester and were Caucasians, and 69.1\% were Catholics. This table also shows that most students affirmed to drink alcohol (58.7\%), had family income up to 3 minimum wages $(39.4 \%)$, were single $(93.3 \%)$ and did not live with their parents $(54.5 \%)$
Table 1. Behavioral and sociodemographic characteristics of the subjects

\begin{tabular}{|c|c|c|}
\hline Variable & $\mathbf{N}$ & $\%$ \\
\hline \multicolumn{3}{|l|}{ Course } \\
\hline Dentistry & 90 & 18.3 \\
\hline Psychology & 75 & 15.2 \\
\hline
\end{tabular}

22.4
Nursing

Pharmacy

Physical Therapy

Physical Education

Semester

1 st to $4^{\text {th }}$

5 th to $10^{\text {th }}$

Race

Caucasian

Mixed black-whites

Indigenous

Black

Other

Religion

None

Catholic

Evangelical

Spiritist

Mormon

No answer

Total

Alcoholism

Yes

No

Total $^{(1)}$

Family income (minimum wage)

Up to 3

4 to 6

7 or more

Marital status

Single

Married

Living with parents

Yes

No

Total

(1): The difference among $\mathrm{n}$ values was due to lack of information.

Table 2 shows a smoking prevalence of 5.7\% and that Psychology undergraduates accounted for the highest percentage of smokers (12.0\%). Among the smokers, more than half (56.3\%) consumed 1 to 3 cigarettes per day and $75 \%$ reported smoking while drinking. Regarding the starting age of smoking, the most prevalent age group was 13 to 18 years $(63.2 \%)$, and stress was the main reason $(36.8 \%)$ alleged by the students. 
Table 2. Prevalence and Academic Profile of Smokers

\begin{tabular}{|c|c|c|}
\hline Variable & $\mathbf{N}$ & $\%$ \\
\hline \multicolumn{3}{|l|}{ Smoking } \\
\hline Yes & 28 & 5.7 \\
\hline No & 464 & 94.3 \\
\hline \multicolumn{3}{|l|}{ Course } \\
\hline Dentistry & 4 & 4.4 \\
\hline Psychology & 9 & 12.0 \\
\hline Nursing & 4 & 3.6 \\
\hline Pharmacy & 5 & 7.0 \\
\hline Physical Therapy & 5 & 6.9 \\
\hline Physical Education & 1 & 1.4 \\
\hline Total & 28 & 5.7 \\
\hline \multicolumn{3}{|c|}{ Consumption of cigarettes per day } \\
\hline 1 to 3 & 9 & 56.3 \\
\hline 4 to 10 & 7 & 43.7 \\
\hline $\operatorname{Total}^{(1)}$ & 16 & 100.0 \\
\hline \multicolumn{3}{|l|}{ Occasion to smoke } \\
\hline Drinking & 12 & 75 \\
\hline feeling like it & 1 & 6.3 \\
\hline Stressed & 3 & 18.7 \\
\hline $\operatorname{Total}^{(1)}$ & 16 & 100.0 \\
\hline \multicolumn{3}{|l|}{ Starting age of smoking } \\
\hline 13 to 18 & 12 & 63.2 \\
\hline 19 or more & 7 & 36.8 \\
\hline Total $^{(1)}$ & 19 & 100.0 \\
\hline \multicolumn{3}{|l|}{ Reason for start smoking } \\
\hline Stress & 7 & 36.8 \\
\hline Influence & 3 & 15.8 \\
\hline Problems with spouse & 1 & 5.3 \\
\hline None & 5 & 26.3 \\
\hline Other reasons & 3 & 15.8 \\
\hline Total $^{(1)}$ & 19 & 100.0 \\
\hline
\end{tabular}

(1): The difference among $\mathrm{n}$ values was due to lack of information.

Table 3 shows that in the total sample, smoking was proportionally higher among students aged over 30 years $(p=0.065)$, males $(p<0.001)$, Caucasians $(\mathrm{p}=0.744)$ and single $(\mathrm{p}=1.000)$, among those not engaged in religious practice $(\mathrm{p}$ $<0.001)$, those in the later semester of the course $(p=0.020)$, those who worked $(p=0.120)$, those with family income higher than 7 minimum wages $(\mathrm{p}=0.819)$, physical activity practitioners $(\mathrm{p}=$ $0.895)$ and alcohol consumers ( $p=0.001)$. After the multivariate analysis by logistic regression, it was found that smoking probability is higher if the student is male ( $\mathrm{OR}=3.29,95 \%$ CI 1.32 to 8.21 and $\mathrm{p}=0.011)$, not engaged in religious practice $(\mathrm{OR}=3.30,95 \% \mathrm{CI} 1.44$ to $7.57, \mathrm{p}=0.005)$, is attending the second half of the course $(\mathrm{OR}=$ $2.45,95 \%$ CI 1.02to $5.87, \mathrm{p}=0.044)$ and is an alcohol consumer $(\mathrm{OR}=3.71,95 \%$ CI 1.06 to $12.47 \mathrm{p}=0.040)($ Table 4$)$.

\section{Discussion}

The WHO considers health professionals as the primary target of antismoking actions $\mathrm{s}^{21}$, as they are future health multiplier agents. In addition, knowing the behavioral and sociodemographic factors of smoking habits provides subsidies to direct the development of research as well as educational and preventive measures on this subject.

The prevalence of smokers among students has been shown to range from $8 \%$ to $52.5 \%{ }^{10}$ ${ }^{12,16}$. In the present study, the prevalence was low $(5.7 \%)$, with no reports of former smokers, following a trend observed in similar studies ${ }^{12,15}$. This result may be due to a greater awareness of the harmful effects of smoking or to well succeed national and state antismoking policies. In this sense, the Paraíba state in Brazil has adopted strict policies, banning smoking in private and public collective environments, and providing educational programs ${ }^{22}$ on the smoking addiction. The Paraíba State University follows an antismoking policy, provides supporting groups for former smokers and those wishing to quit the habit. There are antismoking banners on the campuses, particularly at sectors that offer clinical treatments to the population. The Psychology (12\%) and Physical Education (1.4\%) courses had the highest and lowest prevalence of smokers, respectively. As regards the Psychology course, which is considered as a human science course by other institutions, a health protection attitude did not seem so evident. This result is consistent with those of a previous study reporting higher prevalence of smokers among the human sciences students as compared to health sciences students $(8.7 \% \text { vs. } 3.4 \%)^{23}$. This trend was also noticed in other areas. It has been reported a higher incidence of smokers among exact sciences students compared to health sciences students $(27.1 \%$ vs. $16.3 \%)^{24}$ and among social sciences students compared to health sciences students $(32.9 \%$ vs. $5.6 \%)^{12}$. Specifically in relation to the low prevalence of smokers among physical education students, this may be explained by the fact that these students adopt healthier lifestyles, including regular physical activity.

The number of cigarettes smoked per day is directly related to morbidity and mortality of smokers. Consumption of more than 1 pack per day (> 20 cigarettes/day) increases by 13 times the risk of developing head and neck cancers, while the consumption of 1 to 20 cigarettes per day has been associated with an increased risk of stomach cancer ${ }^{25}$. Most people reported con- 
Table 3. Assessment of smoking habits according to sociodemographic and behavioral variables

\begin{tabular}{|c|c|c|c|c|c|c|c|c|}
\hline \multirow[b]{3}{*}{ Variable } & \multicolumn{6}{|c|}{ Smoking } & \multirow[b]{3}{*}{$P$ value } & \multirow[b]{3}{*}{ OR (IC at $95 \%)$} \\
\hline & \multicolumn{2}{|c|}{ Yes } & \multicolumn{2}{|c|}{ No } & \multicolumn{2}{|c|}{ Total } & & \\
\hline & $\mathrm{N}$ & $\%$ & $\mathbf{N}$ & $\%$ & $\mathrm{~N}$ & $\%$ & & \\
\hline \multicolumn{9}{|l|}{ Age group } \\
\hline 17 to 19 & 4 & 3.6 & 107 & 96.4 & 111 & 100 & \multirow[t]{3}{*}{$\mathrm{p}^{(1)}=0.065$} & 1.00 \\
\hline 20 to 29 & 20 & 5.6 & 335 & 94.4 & 355 & 100 & & $1.60(0.53$ to 4.78$)$ \\
\hline 30 or more & 4 & 15.4 & 22 & 84.6 & 26 & 100 & & $4.86(1.13$ to 20.94$)$ \\
\hline \multicolumn{9}{|l|}{ Gender } \\
\hline Male & 21 & 10.9 & 172 & 89.1 & 193 & 100 & \multirow[t]{2}{*}{$\mathrm{p}^{(1)}<0.001^{*}$} & 5.09 (2.12 to 12.23$)$ \\
\hline Female & 7 & 2.3 & 292 & 97.7 & 299 & 100 & & 1.00 \\
\hline \multicolumn{9}{|l|}{ Ethnical group/Color } \\
\hline Caucasian & 16 & 6.5 & 230 & 93.5 & 246 & 100 & \multirow[t]{4}{*}{$\mathrm{p}^{(2)}=0.744$} & 1.00 \\
\hline Mixed black-white & 8 & 4.3 & 177 & 95.7 & 185 & 100 & & $0.65(0.27$ to 1.55$)$ \\
\hline Black & 2 & 6.3 & 30 & 93.8 & 32 & 100 & & $* *$ \\
\hline Other & 2 & 6.9 & 27 & 93.1 & 29 & 100 & & $* *$ \\
\hline \multicolumn{9}{|l|}{ Marital status } \\
\hline Single & 27 & 5.9 & 432 & 94.1 & 459 & 100 & \multirow[t]{3}{*}{$\mathrm{p}^{(2)}=1.000$} & $* *$ \\
\hline Married & 1 & 3.0 & 32 & 97.0 & 33 & 100 & & \\
\hline Group Total & 28 & 5.7 & 464 & 94.3 & 492 & 100 & & \\
\hline \multicolumn{9}{|l|}{ Religious practice } \\
\hline Yes & 15 & 3.6 & 396 & 96.4 & 411 & 100 & \multirow[t]{3}{*}{$\mathrm{p}^{(1)}<0.001^{\star}$} & 1.00 \\
\hline No & 12 & 15.6 & 65 & 84.4 & 77 & 100 & & $4.87(2.18$ to 10.88$)$ \\
\hline Group Total & 27 & 5.5 & 461 & 94.5 & 488 & 100 & & \\
\hline \multicolumn{9}{|l|}{ Course semester } \\
\hline $1^{\text {st }}$ to $4^{\text {th }}$ & 8 & 3.3 & 238 & 96.7 & 246 & 100 & \multirow[t]{2}{*}{$\mathrm{p}^{(1)}=0.020^{*}$} & 1.00 \\
\hline 5 th to 10 th & 20 & 8.1 & 226 & 91.9 & 246 & & & $2.63(1.14$ to 5.10$)$ \\
\hline \multicolumn{9}{|l|}{ Work outside the home } \\
\hline Yes & 8 & 9.4 & 77 & 90.6 & 85 & 100 & \multirow[t]{2}{*}{$\mathrm{p}^{(2)}=0.120$} & $2.01(0.85$ to 4.73$)$ \\
\hline No & 20 & 4.9 & 387 & 95.1 & 407 & 100 & & 1.00 \\
\hline \multicolumn{9}{|c|}{ Family income (minimum wages) } \\
\hline Up to 3 & 10 & 5.2 & 184 & 94.8 & 194 & 100 & \multirow[t]{3}{*}{$\mathrm{p}^{(1)}=0.819$} & 1.00 \\
\hline 4 to 6 & 10 & 5.5 & 171 & 94.5 & 181 & 100 & & $1.08(0.44$ to 2.65$)$ \\
\hline 7 or more & 8 & 6.8 & 109 & 93.2 & 117 & 100 & & $1.35(0.52$ to 3.53$)$ \\
\hline \multicolumn{9}{|l|}{ Physical activity practice } \\
\hline Yes & 12 & 5.9 & 193 & 94.1 & 205 & 100 & \multirow[t]{2}{*}{$\mathrm{p}^{(2)}=0.895$} & $1.05(0.49$ to 2.28$)$ \\
\hline No & 16 & 5.6 & 271 & 94.4 & 287 & 100 & & 1.00 \\
\hline Alcohol consumption & & & & & & & & \\
\hline Yes & 25 & 8.7 & 264 & 91.3 & 289 & 100 & $\mathrm{p}^{(2)}=0.001^{\star}$ & $6.31(1.88$ to 21.20$)$ \\
\hline No & 3 & 1.5 & 200 & 98.5 & 203 & 100 & & 1.00 \\
\hline Group Total & 28 & 5.7 & 464 & 94.3 & 492 & 100 & & \\
\hline
\end{tabular}

$\left.{ }^{*}\right)$ : significant association at $\left.5.0 \% .{ }^{* *}\right)$ : it was not possible to determine due to the very low frequency of occurrence. (1): by the Pearson's chi-square test. (2): Using the Fisher's Exact test.

sumption of 1 to 3 cigarettes per day, which a lower frequency than that reported in previous reports $^{12,19,23}$.

Most students affirmed that the smoking habit started early, between 13 and 18 years, which is consistent with the literature, since virtually all smokers acquire the habit during adolescence, beginning with a mere trial of a cigarette ${ }^{1,12,10}$. The early starting age of smoking -90\% under 19 years of age - has led the WHO to classify smok- ing among the pediatric diseases, requiring proper diagnosis, treatment and preventive measures $^{26}$. A larger number of smokers were over 30 years of age, though without statistical significance. The 20-40-year-old age group has been described as the one with the highest prevalence of smokers ${ }^{15,21,23}$.

This study revealed that stress was the main reason mentioned to start smoking, as reported elsewhere ${ }^{14,27}$. Although smoking has been asso- 


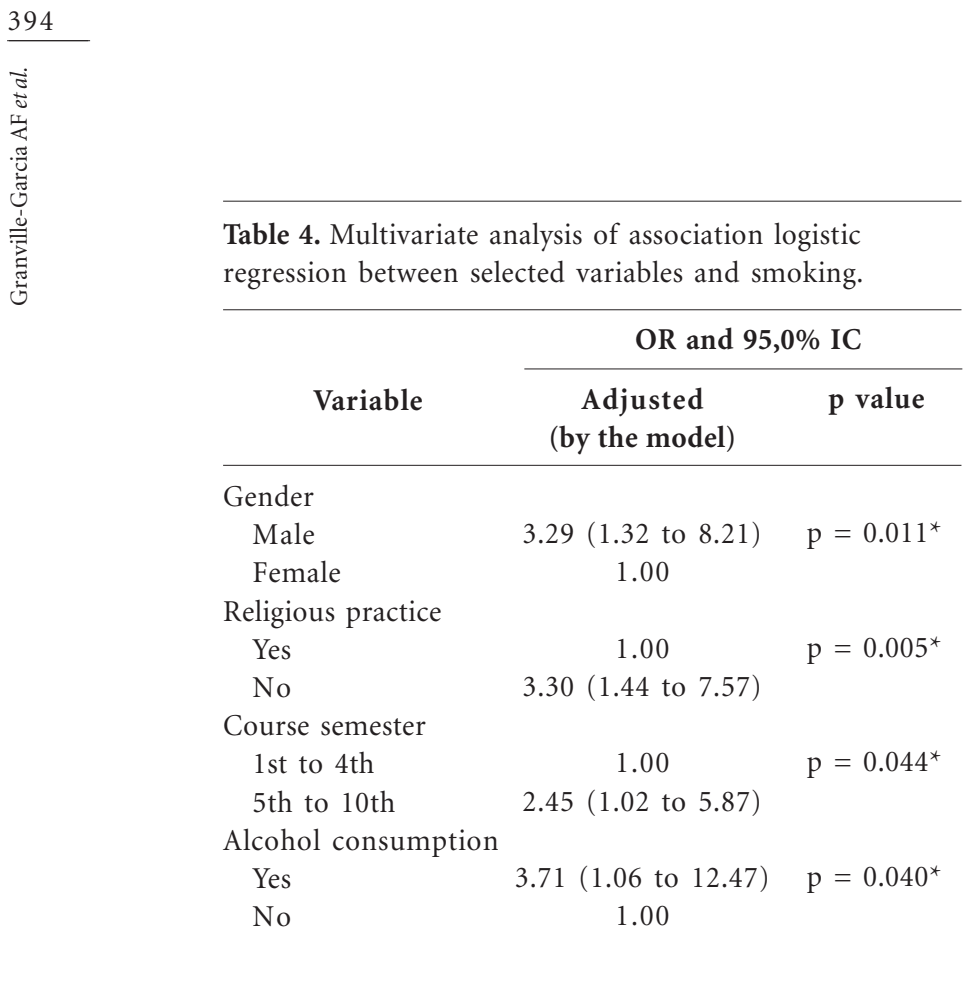

$\left(^{*}\right)$ - significance level at $5.0 \%$.

ciated with emotional stress reduction ${ }^{28}$, friends' influence and curiosity have also been reported as strong reasons for the onset of smoking ${ }^{11,12,20,29}$.

Women have been extensively targeted by the marketing actions of the tobacco industry. For this group, the tobacco industry generally makes advertisements conveying messages of beauty and independence, with young people, photographic models, athletes and ideas that associate cigarette smoking with individual freedom ${ }^{26}$. This approach has resulted in an increase of cigarette consumption. However, in spite of this trend of increase of female consumers ${ }^{21,30}$, there was a higher prevalence among male students $(\mathrm{OR}=$ $3.29,95 \%$ CI 1.32 to 8.21 and $\mathrm{p}=0.011$ ) in the present study. This result is supported by the literature $^{10,19,24}$. This smoker profile has also been reported in young students from the Paraíba capital city in a previous nationwide study ${ }^{26}$.

The prevalence of smokers was similar among ethnical groups with no association between this variable and smoking habit (0.744). On this subject, it has been shown a larger number of smokers among Caucasian and Afro-descendant youngsters ${ }^{11,31}$. There was no association between the marital status and smoking $(\mathrm{p}=1.00)$. Similar results were reported by other authors ${ }^{7,23}$.

Belonging officially to a particular religion is frequently just a formality not likely to influence the behavior ${ }^{14}$. Thus, the subjects were asked if they effectively practiced some religion. It is as- sumed that by practicing a religion the individual belongs to a group with established and shared values and norms, in which there is an explicit and clear condemnation of overall drug use ${ }^{7}$. Confirming these assertions, there was greater chance of being a smoker among students not engaged in religious practice $(\mathrm{OR}=3.30,95 \% \mathrm{CI}$ 1.44 to $7.57, \mathrm{p}=0.005)$. This was also observed in other studies ${ }^{7,20}$.

There was a higher smoking prevalence in the second half of the course $(\mathrm{OR}=2.45,95 \% \mathrm{CI}$ 1.02 to $5.87 \mathrm{p}=0.044$ ) and these data are supported by literature ${ }^{24,27}$. This could be due to the influence of friends, parties, especially if they believe that it is a normal way of relieving stress ${ }^{32}$. In addition, the stress throughout the course may have resulted in the increase in the number of smokers $^{15,16}$, as discussed earlier.

No association was found between working outside the home $(\mathrm{p}=0.120)$, family income ( $\mathrm{p}$ $=0.819$ ) and smoking. The same finding was reported by Rondina et $a l^{23}$. Since the practice of exercise helps maintaining a healthy lifestyle, it was checked if there was a possible association between this variable and smoking. However, there was no significant association between physical activity and smoking $(\mathrm{p}=0.895)$, probably due to the low prevalence of smokers ${ }^{10,20}$.

Tobacco and alcohol use are two major human addictions, and thus a possible association between these variables was also evaluated. Most smokers were alcohol consumers $(\mathrm{OR}=3.71$, $95 \%$ CI 1.06 to $12.47 \mathrm{p}=0.040$ ). In addition, it was found that $75 \%$ of smokers smoked while drinking, suggesting a bidirectional relationship between tobacco and alcohol consumption. However, this relationship can also be unidirectiona ${ }^{33}$. The association between these two drugs has been demonstrated in other studies ${ }^{7,11,20,34}$.

\section{Conclusions}

The knowledge of factors related to smoking is required for the achievement of adequate institutional programs aimed at reducing the number of smokers, especially in the health area. Higher education plays a key role for establishing plans and preventive actions to give the students an opportunity to influence the community where they operate. It is important to notice that the failure to perform the test-retest was a limitation of this study, and for this reason we suggest that they are performed in future studies. The smoking prevalence was low, with early starting 
age and stress as the main reason for smoking. Among the behavioral and sociodemographic variables, gender, semester attended in the course, practice of religion and alcohol consumption were associated with smoking. Based on these results, the authors intend to perform a deeper investigation on this subject, including a qualitative research to evaluate differences in smoking prevalence among the graduation courses as well as the students' perception of smoking. A longitudinal study is also under consideration to evaluate the influence of the established tobacco-free environments at the State University of Paraíba on the decrease of prevalence of smokers among the students.

\section{Collaborations}

\section{References}

DJS Sarmento, JA Santos, TCA Pinto and RV Sousa were responsible for the project design, data collection, database construction and preparation of the manuscript; AF Granville-Garcia was responsible for the project design, research orientation and reviewing the manuscript, $\mathrm{AL}$ Cavalcanti was responsible for reviewing the manuscript.

1. Zanini RR, Moraes AB, Trindade ACA, Riboldi J, Medeiros LR. Prevalência e fatores associados ao consumo de cigarros entre estudantes de escolas estaduais do ensino médio de Santa Maria, Rio Grande do Sul, Brasil, 2002. Cad Saude Publica 2006; 22(8):1619-1627.

2. Silva AO, Sousa CMM, Gaspar MFM, Paredes MAS, Tura LFR, Jesuíno JC. Tabaco e saúde no olhar de estudantes universitários. Rev Bras Enferm 2008; 61(4):423-427.

3. Deheinzelin D, Lourenço MT, da Costa CL, Younes RN. The level of nicotine dependence is an independent risk factor for cancer: a case control study. Clinics 2005; 60(3):221-226.

4. Millar WJ, Locker D. Smoking and oral health status. J Can Dent Assoc 2007; 73(2):155.

5. Oliveira AF, Valente JG, Leite IC. Aspectos da mortalidade atribuível ao tabaco: revisão sistemática. Rev Saude Publica 2008; 42(2):335-345.

6. Malbergier A, Oliveira Júnior HP. Dependência de tabaco e comorbidade psiquiátrica. Rev Psiquiatr Clin 2005; 32(5):276-282.

7. Silva LVER, Malbergier A, Stempliuk VA, Andrade AG. Fatores associados ao consumo de álcool e drogas entre estudantes universitários. Rev Saude Publica 2006; 40(2):280-288.

8. Silva JAA, Amorim C, Rossetto MS, Rodrigues R, Rousseff D, Palocci A. A Convenção-Quadro para o controle do Tabaco. [Atualizada em 02 Jan 2006; acessado 2011 jan 6]. [Documento da Internet]. Disponível em: http://www2.mre.gov.br/dai/m_5658_ 2006.htm

9. Meirelles RHS. A ratificação da Convenção-Quadro para o Controle do Tabaco pelo Brasil: uma questão de saúde pública. J Bras Pneumol [online] 2006; 32(1):ii-iii.

10. Rodrigues ESR, Cheik NC, Mayer AF. Nível de atividade física e tabagismo em universitários. Rev Saude Publica 2008; 42(4):672-678. 
11. Almeida AF, Mussi FC. Tabagismo: conhecimentos, atitudes, hábitos e grau de dependência de jovens fumantes em Salvador. Rev Esc Enferm USP 2006; 40(4):456-463.

12. Andrade APA, Bernardo ACC, Viegas CAA, Ferreira DBL, Gomes TC, Sales MR. Prevalência e características do tabagismo em jovens da Universidade de Brasília. J Bras Pneumol 2006; 32(1):23-28.

13. Wagner GA, Stempliuk VA, Zilberman ML, Barroso LP, Andrade AG. Alcohol and drug use among university students: gender differences. Rev Bras Psiquiatr 2007; 29(2):123-129.

14. Tavares BF, Beria JU, Lima MS. Fatores associados ao uso de drogas entre adolescentes escolares. Rev Saude Publica 2004; 38(6):787-796.

15. Menezes AMB, Hallal PC, Silva F, Souza M, Paiva L, D’Ávila A, Weber B, Vaz V, Marques F, Horta BL. Tabagismo em estudantes de Medicina: tendências temporais e fatores associados. J Bras Pneumol 2004; 30(3):223-228.

16. Franca C, Colares V. Comparative study of health behavior among college students at the start and end of their courses. Rev Saude Publica 2008; 42(3):420-427.

17. Frankfort-Nachimias C, Nachimias D. Research methods in the social sciences. $4^{\text {th }}$ ed. London: Edward Arnold; 1992.

18. World Health Organization (WHO). Definitions of smoking. Geneva: World Health Organization (WHO); 2003.

19. Rodrigues GA, Galvão V, Viegas CAA. Prevalência do tabagismo entre dentistas do Distrito Federal. J Bras Pneumol 2008; 34(5):288-293.

20. Granville-Garcia AF, Branco ACL, Sarmento DJS, Cavalcanti AL, D’Avila S, Menezes VA. Tabagismo e fatores associados entre acadêmicos de odontologia. RFO UPF 2009; 14(2):92-98.

21. Ribeiro SA, Jardim JRB, Laranjeira RR, Alves AKS, Kesselring F, Fleissig L, Almeida MZH, Matsuda M, Hamamoto RS. Prevalência de tabagismo na Universidade Federal de São Paulo, 1996 - dados preliminares de um programa institucional. Rev Assoc Med Bras 1999; 45(1):39-44.

22. Batinga C. Lei no 8.958 de 30 de outubro de 2009. [acessado 2011 jan 6]. [Documento da Internet]. Disponível em: http://alpb.codata.pb.gov.br/sgdd/

23. Rondina RC, Gorayeb R, Botelho C, Silva AMC. A relação entre tabagismo e características sócio-demográficas em universitários. Psicol Saude Doenças 2005; 6(1):35-45.
24. Saleiro S, Damas C, Gomes I. Hábitos tabágicos e conhecimento dos riscos do tabagismo em função da formação acadêmica em estudantes universitários. Rev Port Pneumol 2008; 14(2):231-238.

25. Hoshiyama Y, Sasaba T. A case-control study of stomach cancer and its relation to diet, cigarettes, and alcohol consumption in Saitama Prefecture, Japan. Cancer Cause Control 1992; 3(5):441-448.

26. Mendonça AL, Fernandes EM, Robaina JR, Casado L, Almeida LM, Figueiredo VC, Mesquita A, Cardoso AR, Goldfarb LCS, Silva MRF, Cavalcante T. Vigescola - Vigilância de tabagismo em escolares. Dados e fatos de 12 capitais brasileiras. INCA 2004; 1:1-15.

27. Rondina, RC, Gorayeb R, Botelho C, Silva AMC. Um estudo comparativo entre características de personalidade de universitários fumantes, ex-fumantes e não-fumantes. Rev Psiquiatr Rio Gd Sul 2005; 27(2):140-150.

28. Patton D, Barnes GE, Murray RP. A personality typology of smokers. Addict Behav 1997; 22(2):269-273.

29. Pinto DS, Ribeiro SA. Variables related to smoking initiation among students in public and private high schools in the city of Belém, Brazil. J Bras Pneumol 2007; 33(5):558-564.

30. Horta RL, Horta BL, Pinheiro RT, Morales B, Strey MN. Tabaco, álcool e outras drogas entre adolescentes em Pelotas, Rio Grande do Sul, Brasil: uma perspectiva de gênero. Cad Saude Publica 2007; 23(4):775-783.

31. Machado Neto AS, Cruz AA. Tabagismo em amostra de adolescentes escolares de Salvador-Bahia. $J$ Bras Pneumol 2003; 29(5):262-272.

32. Precioso J. Quando e porquê começam os estudantes universitários a fumar: Implicações para a prevenção. Anal Psicol 2004; 3(XXII):499-506.

33. Colby SM, Lee CS, Lewis-Esquerre J, EspositoSmythers C, Monti PM. Adolescent alcohol misuse: methodological issues for enhancing treatment research. Addiction 2004; 99(Suppl. 2):47-62.

34. Barreto SM, Giatti L, Casado L, Moura L, Crespo C, Malta DC. Exposição ao tabagismo entre escolares no Brasil. Cien Saude Colet 2010; 15(Supl. 2):30273034.

Artigo apresentado em 26/05/2011

Aprovado em 18/09/2011

Versão final apresentada em 25/09/2011 